\title{
EXPERIÊNCIA AMOROSA ON-LINE E NARRATIVA
}

\author{
Vergas Vitória Andrade da Silva*
}

\section{Resumo}

O artigo se propõe a estudar, segundo o olhar da filosofia contemporânea, o fenômeno do namoro virtual através da observação do Orkut, rede social on-line. Para tanto, analisa os debates travados em fóruns e enquetes de uma de suas comunidades virtuais, chamada Conheci meu amor pela internet. A análise empírica demonstra que esses fóruns e enquetes apresentam-se enquanto um fenômeno social que dá origem a uma forma particular de apresentação do eu na internet. No ensejo por apresentarem-se, os mesmos atores acabam por construir narrativas de si. O que se observa nessas narrativas de namoros virtuais é a predominância de uma intriga, cujo desfecho revela-se exitoso, de resultado satisfatório, feliz. Os narradores elegem casos de namoros virtuais que se desenrolam sob a forma de uma felicidade amorosa associada a ideais românticos como dignos de serem retratados. $\mathrm{O}$ teor dessas narrativas é desses aspectos tributário. Portanto, a partir dessas formulações, defendese neste trabalho a tese segundo a qual as narrativas de namoros virtuais são um misto de fato e ficção, na medida em que são narrativas tecidas com empréstimo tanto do imaginário romântico quanto da própria experiência amorosa vivida nos namoros. Em resumo, esta pesquisa esforça-se por compreender fóruns e enquetes cujo cotidiano amoroso é ficcionalizado e dramatizado através de jogos performáticos compostos pela fabulação romântica e pela experiência de concretude dos namoros virtuais.

Palavras-chave: Namoro virtual. Orkut. Fato e Ficção. Narrativas. Amor romântico.

\begin{abstract}
This article aims to acknowledge the virtual dating phenomenon through the eyes of contemporary philosophy. The research deals with this phenomenon in Orkut, a social networking website. Thus, it considers debates and forums that were present in a Brazilian Orkut online community called Conheci meu amor pela internet (I met my love through the Internet). Empirical analysis demonstrates that these forums and polls present themselves as a social phenomenon that allows a particular form of self presentation on the internet. In order for these subjects to present themselves they built their own self narratives. What is possible to acknowledge considering these narratives is that there is a predominance of the element of intrigue that is further solved and demonstrate a satisfactory result. These narrators then choose online dating situation that present happy endings and happiness that are associated to romantic ideals that are worthwhile being shown. The contents present in these narratives are dealt with by the research. Thus, this work defends the thesis that the online dating narratives are a mixture of facts and fiction once all experiences deal with romantic imaginary as well as personal dating experience. Thus, the research is an attempt to understand what goes on the forums and debates that deal with the fictionalized and dramatized daily experiences in the

\footnotetext{
* Doutora em Ciências Sociais pela Universidade Federal do Rio Grande do Norte. Professora de Sociologia do Instituto Federal de Educação, Ciência e Tecnologia do Rio Grande do Norte, Campus Ceará-Mirim/RN. Contato: vitoria.andrade@ifrn.edu.br. CV: http://lattes.cnpq.br/8909456290073930
} 
performances that are similar to games. This is possible due to the fact that there is use of romantic fables and concrete experiences realized by online dating.

Key words: Online Dating. Orkut. Facts and Fiction. Narratives. Romantic Love.

\section{INTRODUÇÃO ${ }^{1}$}

Provavelmente, muitas das situações vivenciadas no campo on-line - como, por exemplo, as postagens ou conversações que se estabelecem por intermédio de chats ou salas de bate-papo, e-mails, Messenger, blogs ou em discussões de fóruns e enquetes - somente adquirem sentido quando são capazes de entretecer os significados disponibilizados contextualmente com a substância viva do narrador. Nessa formulação, fica patente o status dado à forma narrativa: ela é condição para manifestar, comunicar e compreender a própria experiência e a dos outros. Quanto a isso, impera a máxima segundo a qual só se narra o que se compreende. Tal condição, todavia, pressupõe tanto o emprego de palavras em estruturas compreensíveis e lógicas quanto a disposição de códigos sociais e culturais que possibilitem que a narrativa seja inteligível. Nessa prerrogativa, ganha destaque o valor da experiência vivida na concretude do dia a dia como fonte e possibilidade narrativa. Essa ligação entre narrativa e experiência é reiterada por numerosos pesquisadores, a exemplo de Walter Benjamin (1985), em seu famoso ensaio "O narrador" [1936], como uma qualidade comunicativa em crise.

Esse autor denuncia, no contexto moderno, a perda de nossa capacidade de contar e de compartilhar experiências, surgindo assim o que denomina de o fim da arte da narrativa tradicional, da qual dependia essa habilidade. Para Benjamin (1985, p. 201), “o narrador retira[va] da experiência o que ele conta[va]: sua própria experiência ou a relatada pelos outros", entretanto, o caráter abrangente da vida moderna tornou-nos incapazes de permutar tais experiências porque, cada vez mais numerosas, "tornavam-se menos comunicáveis, menos narráveis". (BENJAMIN, 1985, p. 200). Apesar de moderno, trata-se ainda de um fenômeno atual. As pessoas não têm mais tempo para se narrar, narrar para o outro, enfim, para trocar. Múltiplas situações se colocam para o indivíduo hoje que mal dá tempo de experienciar todas, menos ainda de narrá-las. Há uma aridez no campo dialógico - se assim

\footnotetext{
${ }^{1}$ Este artigo é parte integrante de minha tese de doutorado intitulada "Quão romance é minha vida amorosa: namoro virtual e narrativas”, defendida em 2012, no programa de pós-graduação em Ciências Sociais da UFRN.
} 
podemos considerar - e é nessa circunstância que entra a internet como possibilidade de construções de narrativas. Nesse sentido, estamos tomando o universo dos fóruns e enquetes, que discutem namoros virtuais, enquanto um espaço de comunicação no qual narrativas são tecidas e compartilhadas a partir das experiências dos próprios narradores. É evidente que o caráter dessas comunicações tem outra natureza, diferente daquelas problematizadas por Benjamin: essas aqui, acima de tudo, são de ordem virtual. Seja como for, tais narrativas, retiradas da experiência do viver um namoro virtual, são nos fóruns e enquetes contadas e partilhadas. Ademais, trazem sempre a marca do narrador, como também expôs Benjamin (1985, p. 205): "como a mão do oleiro na argila do vaso".

Desse modo, partimos do pressuposto segundo o qual as experiências amorosas, ao serem contadas em fóruns e enquetes, convertem a vida afetiva on-line para o registro da narrativa. Tais experiências são contadas através de imagens (fotos, imagens capturadas que expressam o sentimento, desenhos etc.), frases e poesias de outros, letras musicais e canções, mas aqui estamos nos referindo, especificamente, às narrativas escritas. Assim, ao se tornarem textos escritos, elas passam a ser ordenadas pelas normas de gênero e convenções que governam esse campo. Observamos que essas discussões de namoros virtuais estão norteadas por uma escrita retrospectiva em prosa que pessoas reais fazem de sua própria existência. Trata-se de uma escrita na qual se desvela a relação entre um si mesmo e os próprios namoros virtuais, o que será aprofundado em breve.

Nesse sentido, trabalhamos com o pressuposto de que existe, nas postagens, uma identidade entre o autor, o narrador e o personagem: aquele que escreve e assina o post, contando sua própria vida amorosa, é a mesma pessoa. Com base nesse primeiro pressuposto, tomamos como certas três asserções que guiarão nossa análise: 1) a condição narrativa remete à experiência amorosa on-line para o campo da ficção, no sentido da permanente (re)elaboração das histórias vividas quando do momento de contá-las nos fóruns e enquetes; 2) as tramas narrativas que nos fóruns e enquetes se tecem podem prestar-se ao esclarecimento da própria experiência amorosa; 3) tais debates, ao tornarem-se discurso narrado pela escrita do sujeito - autor e protagonista -, instauram sempre um campo de possibilidade para (re)negociação identitária.

Assim, partindo dessas asserções, os debates sobre namoros virtuais serão considerados, nesta análise, enquanto um tipo de narrativa autobiográfica, mais precisamente, como narrativas de si, extraídas tanto da experiência vivida quanto da ficção, com a finalidade de tecer intrigas sobre relações amorosas exitosas. Nesse ponto, impõe-se a 
necessidade de três tipos de esclarecimentos: um referente ao termo intriga, outro a respeito do por que são as relações amorosas exitosas as consideradas por este artigo e, por fim, a quem essas narrativas se destinam.

Sobre o primeiro esclarecimento, informamos que o termo tessitura da intriga é desenvolvido pelo filósofo Paul Ricoeur (1991, 1994, 1995, 1997, 2000) como uma operação mediante a qual fazemos de nossa vida uma história. A tessitura da intriga transforma uma diversidade de acontecimentos ou de incidentes sucessivos numa história organizada e considerada como um todo. Nessa abordagem, uma história deve ser mais do que uma enumeração de acontecimentos numa ordem seriada, ela deve organizá-los numa totalidade inteligível. A tessitura da intriga é a operação que faz de uma simples sucessão uma configuração. Desenvolveremos essa perspectiva nas páginas que seguem.

No que diz respeito ao segundo esclarecimento, é mais uma vez importante lembrar aqui que não tivemos acesso ao material trocado entre os pares amorosos (fotos, imagens, poesias, cartas etc.), mas ao que eles contam nos fóruns e enquetes. Nesse material, aparecem com maior expressão as histórias de amor bem-aventuradas. Percebemos que há por parte dos narradores uma eleição por contar histórias de namoros virtuais com resultados felizes, contudo, isso não significa dizer que não haja histórias de namoros virtuais malogradas nos fóruns e enquetes estudados, prevalecendo aquelas que apresentam bom êxito, as quais nos chamam a atenção. Finalmente, a eleição deles pelas bem-aventuradas histórias fez-nos levantar diversas questões que procuraremos responder neste artigo, apresentando, para tanto, uma hipótese mais adiante.

Quanto ao terceiro esclarecimento, afirmamos que essas são as narrativas que têm como interlocutor privilegiado, para quem o narrador(a) dirige sua produção narrativa, os demais membros que compõem a comunidade de namoros virtuais. Cada narrativa produzida visa esses potenciais interlocutores, com quem se deseja tecer relações de reciprocidade e permuta. Nesse sentido, os narradores apresentam uma intenção bastante clara no ato de narrar suas histórias: que elas sejam lidas e comentadas. Sem esse suporte em vista, eles não teriam por que produzi-las.

No que concerne a essas narrativas de si, tecidas como intrigas sobre relações amorosas exitosas, estamos trabalhando com dois conjuntos de hipóteses - as consideradas gerais e as específicas. Comecemos com as primeiras: ao contar histórias de namoros virtuais nos fóruns e enquetes, os indivíduos estarão submetidos, inevitavelmente, à forma narrativa e à (re)construção dos fatos. Suas narrativas surgem aí como possibilidade para uma 
interpretação do si, realizando empréstimos à história bem como à ficção, ambas concernindo ao próprio indivíduo. Nas discussões de namoros virtuais, os indivíduos poderão criar uma imagem de si próprios e das relações amorosas que, em verdade, constituem uma instância da realidade relativa à sua maneira de representar a própria existência pessoal e afetiva. É desse modo que atribuímos a essas narrativas o caráter romanesco e imaginário. Porém, em que sentido? No sentido de que os autores dos fóruns e enquetes elaboram as histórias (narrativas) da vida amorosa como uma interpretação, ou seja, como construção imaginário-ficcional de um indivíduo que ao debruçar-se sobre si e seu vivido poderá reconstituí-lo, isso porque "é precisamente em razão do caráter evasivo da vida real que temos a necessidade do auxílio da ficção para organizar esta última retrospectiva extemporânea, com o risco de considerar revisível e provisória toda figura da intriga emprestada da ficção ou da história”. (RICOEUR, 1991, p. 192).

Nossas hipóteses específicas giram em torno das seguintes afirmações: nos fóruns e enquetes, a reconstituição ou (re)elaboração do vivido amoroso dá-se sob a face de uma história feliz. Essa reelaboração está baseada numa intriga em que a relação virtual e o amor romântico são apresentados como fortunas prósperas. Em consequência, o si aparece revestido sob a representação de uma pessoa enormemente feliz por viver tal amor. São narrativas em que tanto os namoros virtuais quanto o amor romântico emergem como um estado durável de felicidade contínua, aparecendo associados a boa fortuna, sorte, presente de deus. Os narradores, nas discussões sobre namoros virtuais, procuram romancear suas relações amorosas e o próprio amor romântico, e é nesse processo que entrecruzam invenção e experiência amorosa vivida como protótipo da felicidade. Quando os indivíduos se dirigem aos fóruns e enquetes com a intenção de postar trechos de sua vida amorosa, eles não apenas sofrem a influência do afastamento temporal que opera em todo processo de reminiscência, apagando determinadas experiências e intensificando outras, mas também operam uma seleção ao escolher os fatos considerados dignos de serem divulgados e ao privilegiar determinados aspectos em detrimento de outros, buscando, em certa medida, dar sentido ao relato da própria vivência. Nesses casos, selecionam histórias em que o namoro virtual e o amor romântico aparecem como eternos estados de contentamento, satisfação, alegria.

Adiante, demonstraremos tais hipóteses através da apresentação de narrativas correntes nos fóruns e enquetes, observando, reiteradamente, que nelas reúnem-se os elementos que deflagram uma interconexão bastante próxima entre sentimento amoroso, relação virtual e felicidade amorosa. O amor romântico e o namoro virtual nessas elaborações 
narrativas surgem como o símbolo da máxima felicidade, ou seja, a representação que constroem do estar feliz passa a ser um componente indispensável nos fóruns e enquetes. Trata-se de um tema central: a expressão pública da felicidade gerada pela experiência de viver um amor virtual. Em resumo, a experiência amorosa do namoro virtual aparece nessas narrativas como um estado afetivo bem-sucedido associado a sentimentos de bem-estar e prazer que podemos traduzir pelo signo da felicidade amorosa, a qual corresponde a uma categoria valorativa. Ela é um combinado de valores, crenças, pensamentos, julgamentos e conceitos que aqueles que narram as histórias de namoros virtuais constroem como sendo sua felicidade amorosa.

\section{NAMOROS VIRTUAIS E NARRATIVAS}

Sob o ângulo teórico, temos na abordagem das narrativas a filosofia de Paul Ricoeur (1991, 1994, 1995, 1997, 2000), que é considerada uma referência para muitos estudos. Nela, interessa-nos o mote no qual o autor estabelece um vínculo muito próximo entre os modos de o sujeito compreender-se a si mesmo e ao mundo que o rodeia através do processo de elaboração de narrativas. Nas formulações de Ricoeur, a ação narrativa é tomada como experiência de compreensão humana. Assim, o que constitui um discurso e torna possível uma situação de comunicação é a condição do sujeito, que leva a linguagem e compartilha com outrem uma experiência, a qual somente pode ser narrada. Observaremos a seguir que é a partir dessa perspectiva teórica que estaremos considerando as narrativas sobre namoros virtuais enquanto possibilidade de o indivíduo compreender-se, mesmo que não tenha consciência do processo enquanto tal. O que se vê nos discursos é uma expressão segundo a qual o ato de narrar ou contar faz com que se sintam melhores.

A narrativa contribui, segundo os próprios narradores, para um processo que traduzem como alívio. Como exemplo, destacamos duas declarações, a saber, a de Amanda: Ah, estou muito melhor agora, depois de ter escrito isso. Parei de chorar... Bom, é isso, escrevam suas histórias aqui também; e a de Leandro: Obrigado por deixarem eu ter meu espacinho aqui para me abrir, expressar e falar o que sinto. Estou melhor e mais esperançoso. Seja como for, o uso do termo compreensão é somente considerado válido quando colocado como um campo de possibilidade. O que importa é que a forma narrativa configura-se como um dos elementos que tornam possível a compreensão da experiência (oral, visual ou escrita). Os fóruns e enquetes sobre namoros virtuais são, em verdade, espaços 
nos quais indivíduos dão forma às suas experiências, comunicam as situações e os eventos de suas existências amorosas afetivas, mas também inscrevem o curso de suas vidas no ambiente social e histórico.

Em Tempo e narrativa I, Ricoeur (1994, p. 15) nos convoca a repensar a questão da narrativa, atestando que "o desafio último da identidade estrutural da função narrativa é o caráter temporal da existência humana". Nessa perspectiva, "o mundo exibido por qualquer obra narrativa é sempre um mundo temporal", desse modo, "o tempo torna-se tempo humano na medida em que está articulado de modo narrativo"; em compensação, "a narrativa é significativa na medida em que esboça traços da experiência temporal”. Evidencia-se, nessa formulação, a existência de uma conexão significativa entre a função narrativa e a experiência humana do tempo. Nessa prescrição argumentativa, a trama narrativa, reiteradamente, é um meio privilegiado para esclarecer a experiência. É, pois, aprofundando mais nessa dimensão temporal da experiência humana que se acha na filosofia de Ricoeur a probabilidade de entender as narrativas como formas de constituição do sujeito e, nesse caso, espaço para interrogação e problematização do si e, respectivamente, do outro, elaborados seja em forma literária, seja em narrativas autobiográficas ou de memória, seja em narrativas de ficção.

Baseando-nos nesse aspecto da abordagem, já temos condição de apresentar argumentos teóricos para defender três assertivas referentes ao nosso campo empírico, quais sejam: 1) os fóruns e enquetes sobre namoros virtuais, convertidos em narrativas escritas, servem-se tanto da história vivida quanto da ficção. As narrativas sobre namoros virtuais apresentam-se, assim, como um conjugado entre experiência amorosa on-line e fabulação; 2) nesses fóruns e enquetes, a vida amorosa pode tornar-se mais legível, pois é contada pela pessoa que a viveu ou vive. Ela (talvez, o fato amoroso) converte-se assim em uma história mais nítida para si graças à mediação da narrativa, que pode aclarar a experiência; 3) ao contarem sobre seus namoros virtuais, poderão desvelar, em consequência, quem são. Ao postarem nos fóruns e enquetes suas experiências amorosas on-line os indivíduos estão, concomitantemente, respondendo à pergunta: quem sou eu? Trata-se de um espaço de possibilidade de (re)construção de identidades.

Isso dito, estamos bem situados na perspectiva teórica de Ricoeur (1991, 1997, 2000), especialmente através da noção que denomina de identidade narrativa, ou seja, "o tipo de identidade à qual um ser humano acede graças à mediação da função narrativa". (RICOEUR, 2000, p. 177). O filósofo chega a essa noção no final do livro Tempo e Narrativa III. Em suas palavras: 
Confrontei-me com este problema no fim de Temps et récit III, quando me interroguei, no termo de uma longa viagem através da narrativa histórica e da narrativa de ficção, se existia uma experiência fundamental capaz de integrar os dois grandes conjuntos de narrativas. Formei então a hipótese segundo a qual a constituição da identidade narrativa, seja de uma pessoa individual, seja de uma comunidade histórica, era o lugar procurado desta fusão história e ficção. (RICOEUR, 2000, p. 178).

Uma conclusão previsível que daí decorre é que a identidade narrativa seria um termo atribuído a uma hipótese teórica que propunha a articulação entre as narrativas histórica e ficcional, como modo de configurar o tempo humano. A respeito da reciprocidade entre narratividade e temporalidade, assevera-nos Ricoeur (1997, p. 417): “de forma esquemática, a nossa hipótese de trabalho equivale a considerar a narrativa como guardião do tempo, na medida em que só haveria tempo pensado quando narrado". No interior dessa mesma asserção, é importante perceber que, segundo Ricoeur (1997, p. 317), “a história se serve, de algum modo, da ficção para refigurar o tempo e, por outro lado, a ficção se vale da história com o mesmo objetivo". Teremos chance a seguir de demonstrar que esse aspecto, referente à articulação entre ficção e história, será a base para refletirmos as narrativas sobre namoros virtuais. Por agora, notemos como Ricoeur (2000, p. 178), partindo dessa hipótese específica, apresenta uma compreensão bastante interessante:

Não se tornam as vidas humanas mais legíveis quando são interpretadas em função das histórias que as pessoas contam a seu respeito? E estas histórias da vida não se tornam elas, por sua vez, mais inteligíveis, quando lhes são aplicadas modelos narrativos - as intrigas - extraídas da história e da ficção (drama ou romance)?

Tal formulação compreensiva induz Ricoeur (2000, p. 178) a ter como válida a seguinte cadeia de asserções:

O conhecimento de si próprio é uma interpretação, - a interpretação de si próprio, por sua vez, encontra na narrativa, entre outros signos e símbolos, uma mediação privilegiada -, esta última serve-se tanto da história como da ficção, fazendo da história de uma vida uma história fictícia ou, se se preferir, uma ficção histórica, comparáveis às biografias dos grandes homens em que se mistura a história e a ficção.

No que concerne especificamente ao entrecruzamento da história e da ficção, observamos que Ricoeur (1997) parte dos pressupostos do historiador Hayden White (1994). Ambos os autores defendem que a história e a ficção trabalham com o mesmo material. De maneira a 
aclarar tal concepção, Ricoeur (1997) opta por analisar a ficcionalização da história, já que nas narrativas históricas o imaginário é vinculado às considerações do ter sido. Entretanto, isso não significa em nada invalidar a matiz realista desses estudos. O imaginário representaria, para Ricoeur, o ponto fundamental para a construção da história. A hipótese que o autor levanta é a de que "a ficção é quase histórica, tanto quanto a história é quase fictícia". (RICOEUR, 1997, p. 329). Nessa perspectiva, a narrativa histórica, como a narrativa de ficção, tem como referente comum o caráter temporal da experiência. Assim, tanto a história como a narrativa fictícia correspondem a uma única operação configurante que mune ambas de inteligibilidade e vincula entre elas uma similitude essencial.

Tal operação é a intriga, através da qual os acontecimentos particulares e distintos adquirem categoria de história ou narrativa. É esse enredo em ação, concebido como uma operação de configuração, que Ricoeur nomeia sob o termo tessitura da intriga, característica essencial, segundo o autor, de toda narrativa. Essa operação de configuração é fundamentalmente uma operação discursiva. É a narrativa, como gênero do discurso, que não é exclusivamente o meio, mas também o lugar dessa operação. O que se defende aqui é que a história de vida das pessoas se elabora na narrativa, ou seja, o que dá forma ao vivido e à experiência dos homens são as suas narrativas, como espaço no qual o indivíduo toma forma, engendra e experimenta a história de sua vida. Poderíamos dizer, tal qual Delory-Momberger (2008, p. 98) em sua apropriação de Ricoeur: a "história de vida que, tal como a constrói a narrativa, é a ficção verdadeira do sujeito: é a história que o narrador, no momento em que enuncia, toma por verdadeira e na qual se constrói como sujeito (individual e social) no ato da enunciação".

Essa perspectiva dá-nos respaldo para pensarmos que nas narrativas de si, tecidas nos fóruns e enquetes sobre namoros virtuais, pouco interessa se a pessoa diz efetivamente a verdade: é a intenção de engendrar um discurso da verdade que realmente importa. Nesse sentido, um autobiógrafo "não é alguém que afirma a verdade de si mesmo, mas alguém que diz que a disse". (LEJEUNE, 1998, p. 125 apud BOUILLOUD, 2009, p. 36). Assim, a narrativa autobiográfica mostra-se e consolida-se como um verdadeiro relato para o próprio autor. O que realmente vale é a configuração do relato proposto como veraz. Na elaboração da narrativa, além da história que o autor busca narrar, há outros aspectos de igual modo significativos, como "seus sentimentos, as suas emoções, as suas reflexões pessoais e, além disso, o reflexo das categorias, dos sistemas de valores ou experiências comuns nas quais o autor se inscreve". (BOUILLOUD, 2009, p. 36). Saber se tal ou qual evento de fato 
aconteceu, da forma como está descrito, "é de certa maneira secundário em relação à toda abertura de análise que a apreensão da autobiografia em sua inscrição social permite”. (BOUILLOUD, 2009, p. 37).

Tornemos a problematizar a questão da identidade narrativa, noção cara aos desígnios deste artigo. Indubitavelmente, é dos intercâmbios íntimos entre historicização da narrativa de ficção e ficcionalização da narrativa histórica que surge esse termo. Nas palavras de Ricoeur (1997, p. 424):

\begin{abstract}
O frágil rebento oriundo da união entre a história e a ficção é a atribuição a um indivíduo ou a uma comunidade de uma identidade específica que podemos chamar de identidade narrativa. O termo "identidade" é aqui tomado no sentido de uma categoria prática. Dizer a identidade de um indivíduo ou de uma comunidade é responder à questão: quem fez tal ação? Quem é o seu agente, o seu autor? [...] A resposta só pode ser narrativa. Responder à questão quem?, como o dissera energicamente Hannah Arendt, é contar a história de uma vida. A história narrada diz o quem da ação. A identidade do quem é apenas, portanto, uma identidade narrativa.
\end{abstract}

Como se depreende, para Ricoeur (1997), responder a questão “quem?” é dizer “quem é o agente, o autor da ação". Por conseguinte, dizer “quem é o autor da ação" é contar a história de uma vida. A identidade narrativa é, pois, a história de uma vida narrada, sendo também, convencionalmente, definida por Ricoeur (1991) como a identidade do personagem. Trata-se de uma identidade compreendida por meio da narrativa e que é construída no plano da intriga. Por essa apreensão, a pessoa é entendida como a personagem da narrativa, pois não é distinta de suas próprias experiências. Isso quer dizer que os acontecimentos que a pessoa experiência são configurados pela narrativa, resultando em uma história relatada que teve origem na identidade dinâmica da personagem. A narrativa, assim, constrói a identidade da personagem, a qual é chamada identidade narrativa, que, por sua vez, constrói a identidade da história relatada.

É a partir daí que Ricoeur (1991) postula que a narrativa pode e dá ao sujeito não apenas a chance de pensar sobre si, mas também de contar sobre si. Partindo dessa problematização, da decifração do quem do narrador, no livro $O$ si mesmo como um outro, sequência de Tempo e Narrativa, Ricoeur (1991) recupera, especialmente em seu quinto estudo, a discussão sobre identidade narrativa, não mais partindo da narrativa como constituinte da temporalização do humano, mas sim da narrativa como constituição do si. Esse estudo - o quinto - teve por objetivo "preencher uma grande lacuna referente à questão da 
identidade pessoal, que só pode se articular na dimensão temporal da existência humana”. Para tanto, Ricoeur (1991, p. 138) recomeça seu trabalho "da teoria narrativa, por meio da perspectiva da constituição do si”. Esse viés leva-nos a perceber como o tempo é um dos principais fatores que devem ser levados em conta na compreensão das identidades, pois, nessa dimensão teórica, a narrativa concentra e se constitui como um lugar de convergência temporal. Nesse sentido, configura-se o mote para começar a pensar a questão.

Por último, ainda no interior dessa perspectiva, temos que a experiência da narração é também aquela que converte o vivido no contado, isto é, consiste na configuração dos acontecimentos da vida em uma intriga que, em consequência, permite uma refiguração dessa mesma vida, dotando-a de uma identidade narrativa que pode ser interpretada e compreendida. (RICOEUR, 1991, 1997). O que está em jogo, nessa abordagem, é essa capacidade de a vida contada tornar-se uma referência da identidade e dar ao autor da narrativa a satisfação de ver-se a si mesmo representado enquanto personagem de uma história que ele viveu e que pode contar. Nesses casos, autor, personagem e narrador se confundem, sem, entretanto, serem os mesmos. Daí não se pode dizer que a vida contada e narrada seja a vida vivida, porque o próprio autor não é, em essência, aquele cuja história está sendo exposta.

Diante das formulações teóricas discutidas acima, interessam-nos, mais especificamente - para dar conta da nossa questão de pesquisa, qual seja, as discussões sobre namoros virtuais -, dois argumentos em especial, a respeito dos quais se assentará nossa análise doravante. Ambos são extraídos da compreensão de Ricoeur (1997, p. 12), segundo a qual a identidade narrativa seria um lugar privilegiado da fusão entre história e ficção e, em consequência, de aparecimento da identidade do personagem, que surge como resposta à questão: quem fez a ação? Mais uma vez, o personagem (ou sua identidade) é aquele que realiza a ação na narrativa elaborada no plano da intriga. É por isso que a narrativa constrói a identidade do personagem. Após esse esclarecimento, passemos de imediato à apresentação dos dois argumentos referidos acima.

Primeiro, estamos ancorados no seguinte argumento: a vida narrada não equivale à vida vivida, ao menos em sua totalidade. O que importa aqui é a ordem da representação que faz o personagem de sua vida, ou de aspectos dela, mais do que a ordem factual dos acontecimentos "reais". Nesse sentido, queremos demonstrar como o exercício narrativo de si, 
que se verifica nas discussões de namoros virtuais, é marcado por uma ficcionalidade, e não por um falseamento. Uma ficcionalidade que é da própria forma narrativa. Estamos ancorados na assertiva de Ricoeur $(1991,1997)$, segundo a qual a narrativa autobiográfica oferece ao narrador a possibilidade de ficcionalizar sua vida, elaborando-a como intriga que se realiza em narração. No que concerne ao nosso campo empírico, contar a vida amorosa em fóruns e enquetes, evento marcado por experiências diversas, é tramar essa mesma vida, dando-a, quando possível, um sentido, uma forma e, decerto, expondo uma concepção de mundo. A partir de tais afirmativas, é possível tomar as discussões sobre namoros virtuais não como a vida vivida, mas como a vida contada por um autor (ou narrador). Esses fóruns e enquetes são tomados, portanto, não como o curso efetivo real da vida amorosa, e sim como a representação construída da existência através das operações da prática de narrar, de relatar, de construir enredos.

O segundo argumento pelo qual se encontra assentada nossa análise é aquele que versa sobre a trama narrativa como meio potencial para aclarar a experiência amorosa. Ricoeur (1991), com base em sua teoria geral da narrativa, desenha a ideia de tomar a identidade da personagem de uma intriga como configuração da identidade narrativa do si mesmo. Assim, a categoria identidade narrativa apresenta-se como sendo um tipo de intriga em que cada sujeito se encontra implicado, mas que sua origem e fim não têm controle, sendo a sua tarefa própria apenas a de lhe conferir sentido. Em nosso caso, esse sentido é conferido segundo o interlocutor em face da relação amorosa. A partir dessa abordagem, podemos inferir que cada sujeito personagem nos fóruns e enquetes narra, narra-se, como forma possível de responder à questão: quem sou eu? Mais uma vez aqui, isso ocorre mesmo que não tenham consciência do processo enquanto tal, pois não se trata de um dispositivo terapêutico ou reflexivo em que se induz o pensamento para essas indagações. Cada vez mais, nesse ato de narrar ou narrar-se, configura-se uma atitude segundo a qual o conhecimento de si pode gerar uma interpretação da vida amorosa. Somente a história narrada diz o quem da ação. As narrativas contadas acerca da vida afetiva poderão dar sentido aos acontecimentos dos quais se tem a experiência. Aqui, a identidade do personagem não é imposta por uma história posta em ato, mas é narrando as histórias da própria vida amorosa que se torna possível sua descoberta.

A partir de Ricoeur, chamamos a atenção, em definitivo, para o caráter ficcional das histórias de vida amorosa quando fixadas por meio da forma narrativa. Nos fóruns e enquetes sobre namoros virtuais, reiteradamente, o formato ficcional que emoldura as narrativas de si 
pode ser lido como romanesco. Os sujeitos que participam dessas discussões mostram-se, então, constituídos ao mesmo tempo como leitores e escritores de sua própria vida, mesmo quando não é esse o objetivo, visto que narram suas histórias com objetivos diversos. A esse respeito, apontamos como exemplos: postar questões relativas a dúvidas e angústias a respeito de seus namoros; fazer pedidos de ajuda a membros que já são experientes no quesito namoro a distância; fazer desabafos frente a sofrimentos, alegrias, medos, incertezas; pedir ajuda para reconquistar um amor; avisar sobre casamentos e encorajar outros internautas com falas de incentivo; falar sobre nascimento de filhos (de pais que se conheceram na internet); relatar suas queixas e desilusões a respeito de seus parceiros; fazer advertências àqueles ainda inexperientes no namoro via internet; relatar desapontamentos diante do primeiro encontro presencial; descrever como foram enganados(as) por seus parceiros(as); oferecer conselhos para suportar bem a saudade e a ausência; descrever fins de namoro; fazer declarações de amor etc.

Como a análise sobre autobiografia verifica, "a história de uma vida não cessa de ser refigurada por todas as histórias verídicas ou fictícias que um sujeito conta sobre si mesmo. Essa refiguração faz da própria vida um tecido de histórias narradas" (RICOEUR, 1997, p. 425), como as que surgem reinventadas nos fóruns e enquetes, em que o namoro virtual emerge sob a forma de uma narrativa que entrecruza amor romântico e felicidade. Visualizaremos melhor, na seção deste artigo que discutirá a ficcionalização das histórias de amores felizes, os desdobramentos dessa proposição.

\section{NAMOROS VIRTUAIS E IDENTIDADE NARRATIVA}

Nossa linha argumentativa, até aqui, assevera que as narrativas de namoros virtuais tecidas nos fóruns e enquetes são particularmente adequadas ao gênero autobiográfico, isto é, em termos processuais, narrativas similares a esse gênero. Entretanto, interessa-nos ainda delinear suas possíveis especificidades. A questão que se impõe a esse ponto é: o que há de particular nas formulações dessas narrativas às quais denominamos narrativas de si? Antes de discutirmos esse problema, será conveniente fazer algumas considerações mais gerais sobre tais narrativas, demarcando suas principais características. Destacamos quatro delas como centrais:

- As narrativas de namoros virtuais são sempre momentâneas e situacionais, dado a própria dinâmica da ferramenta Orkut e a natureza volátil das 
identidades e das relações sociais que ali se estabelecem. Longe de surgirem enquanto textos fixos, elas aparecem como uma forma de expressão inserida no fluxo diligente da ação social on-line;

- São narrativas performáticas que organizam e expressam a experiência de viver um namoro virtual. É ainda importante advertir que os participantes dessas performances não necessariamente partilham da mesma experiência ou significado comuns aos demais;

- Essas narrativas formam uma unidade entre texto e ação, constituindo e ordenando a experiência bem como podendo servir para reflexão e comunicação desta. As narrativas criam uma experiência ao mesmo tempo que podem refletir sobre ela;

- São narrativas que apresentam caráter hermenêutico, pois presumem, como um possível constituinte de sua ação, a probabilidade da reflexividade. Nelas, encontra-se um ativo processo de (re)negociação e (re)elaboração no qual os participantes poderão examinar reflexivamente o discurso no momento em que ele está emergindo.

A respeito dessa última característica, é necessário explicitar melhor a natureza dessa reflexividade. Estamos partindo de um pressuposto teórico em que a ação narrativa pode ser tomada como experiência de compreensão humana, na medida em que através dela é possível ao indivíduo manifestar e comunicar a experiência. Ao colocar as experiências vividas sob a forma narrativa, tornamo-las mais inteligíveis, residindo aí a possibilidade de reflexividade a que nos referíamos. Aqui, queremos deixar claro que as narrativas de namoros virtuais não equivalem a um dispositivo com fim próprio a suscitar reflevixidade, mas há possibilidades de que assim ocorra.

A partir dessas quatro características, estamos considerando que as discussões sobre namoros virtuais, da forma como estão escritas, isto é, postas no formato narrativo, podem vir a aclarar para o narrador os próprios namoros e certos traços de sua vida. Nessa perspectiva, os fóruns e enquetes podem tornar-se espaços destinados à interrogação e à problematização dos namoros, na mesma medida em que podem vir a ser convertidos em espaços para interrogação e problematização do si. Nesse ponto, poderemos abrir um breve parêntese de modo a refletirmos sobre o caráter precário e fluído em que tal problematização emerge em nossa sociedade atual, não sendo como na Grécia antiga, onde existiam suportes sociais e culturais para esse exercício. Como muito bem assinala Foucault (2006), eles viviam numa cultura de si. Conforme está problematizado na obra A hermenêutica do sujeito (2006) desse 
autor, o cuidado de si, reflexo dessa cultura, articulava-se, necessariamente, com o conhecimento de si.

Nas palavras de Foucault (2006, p. 310), “toda a superfície do cuidado de si é ocupada pelo imperativo do conhecimento de si, conhecimento que, como sabemos, toma a forma de apreensão pela alma de seu ser próprio". É interessante que, de acordo com esse autor, na Antiguidade grega o conhecimento de si era alcançado através de práticas que, em maior ou menor grau, envolviam leituras, escritas sobre si e relações no mundo e, consequentemente, interpretações. Dessa perspectiva, interessa aos desígnios deste trabalho de tese o fato de que o sujeito é interpretante do mundo, da natureza e do outro, porém não deixa de ser interpretado. É na dinâmica de um sujeito simultaneamente intérprete e objeto interpretado que ele dirige sua atenção para o si e também se interpreta, como muito bem demonstrou esse filósofo em inúmeros momentos do curso A hermenêutica do sujeito. Fechemos aqui o parêntese para introduzir, a seguir, uma breve advertência.

Nesta nossa pesquisa, é importante esclarecer a seguinte relação: o processo de problematização e interpretação de si nos fóruns e enquetes sobre namoros virtuais. Ambas as operações - problematização e interpretação de si - equivalem, em nossa pesquisa, a um campo de possibilidade, e não de certeza. Não poderemos afirmar que os narradores de namoros virtuais estejam conscientes que ao postarem em fóruns e enquetes passam, por sua vez, a compreender melhor o seu vivido. Os fóruns e enquetes, na percepção dos membros do Orkut, não são vistos como um dispositivo que os leva à compreensão ou à reflexividade, mesmo por que tais mecanismos de comunicação não foram criados e estabelecidos com tal fim. Defendemos aqui que tais problematizações e interrogações, tanto do si quanto dos namoros, são fenômenos possíveis de ocorrer, visto que as discussões de namoros virtuais nos fóruns e enquetes estão postas em formato narrativo e, conforme, nossa orientação teórica, as narrativas são consideradas campos de compreensão humana.

Desse modo, tendo em vista a noção ampliada de narrativa enquanto condição de produção de sentidos e identidade de personagem, inferimos que nos depoimentos que trazem trechos de vida, presentes nos fóruns e enquetes, tecem-se intrigas que configuram os próprios namoros virtuais enquanto campo social e evento histórico durável. As discussões sobre namoros virtuais, nessa abordagem, são tomadas como constituindo uma narrativa, dentro da qual os sujeitos já estão situados quando começam a contar sua história pessoal, como aqueles que namoram virtualmente. Quando enfocamos as discussões que se estabelecem nos fóruns e enquetes e sua confluência na constituição dos namoros virtuais, 
notamos aí as marcas que configuram esse espaço como um possível campo para a constituição de uma identidade narrativa que torna possível que sujeitos, desde sempre imersos na historicidade e na linguisticidade, possam diligenciar os fatos de acordo com uma perspectiva que os leve, em certa medida, a compreender e comunicar certa experiência pessoal e social.

Novamente, as narrativas de si que se veem através das discussões de namoros virtuais também podem ser consideradas como ficcionais, a partir das quais lembrar e contar é poder reorganizar e reconstruir a identidade narrativa, isto é, a personagem narrativa, conforme discutido acima. Essa autoinvenção, por sua vez, pode trazer consigo a invenção do outro, das relações de alteridade e, portanto, da identidade narrativa do campo cultural em questão (o amoroso). O que está sendo inventado no ato narrativo autobiográfico das discussões de namoros virtuais, para além da individualidade das vidas narradas, pode ser postulado nos termos de uma identidade narrativa que ao mesmo tempo demarca o campo amoroso e a ação dos sujeitos dentro dele. Essa possível construção identitária, tomada do ponto de vista dos atores, evidencia um sujeito que é levado a pensar sua vida afetiva. Essa mesma construção identitária, sempre móvel, instaura-se enquanto horizonte de uma possível atribuição de sentido para si e para os próprios namoros, de tal modo que nas narrativas de namoros virtuais verifica-se uma relação íntima entre identidade (personagem), sentimentos e relação amorosa, assentando-se aí sua particularidade. Elas são elaboradas com recursos da experiência vivida e da ficção, dessa maneira a vida amorosa narrada não é igual à vida amorosa vivida. Ao contrário, são narrativas de namoros virtuais que revelam o quem da ação no processo contínuo de construção de identidades em que os namoros virtuais aparecem associados à felicidade amorosa contínua.

A análise empírica demonstra que as histórias de vida amorosa relatadas nos fóruns e enquetes se elaboram na narrativa, mais precisamente numa intriga que se desenrola sob o modo de uma história de amor feliz. É essa última que dá forma ao vivido e à experiência, fazendo da história de uma vida amorosa on-line uma história fictícia ou uma ficção histórica em que imperam expressões, tais como: Estou muito feliz. Encontrei o amor da minha vida; Minha felicidade é percebida por todos; Somos muitos felizes e a cada dia mais apaixonados um pelo outro; Estou muito feliz e tenho certeza ser ele o amor da minha vida; Estou feliz como nunca havia sido antes; Seremos felizes eternamente; Nos completamos e somos felizes; Estamos felizes sim pela forma como Deus nos aproximou; Estamos muito felizes com nossa escolha; Estou muito feliz. Hoje meu amor me pediu em namoro. Espero que o meu namoro 
seja feliz e duradouro como o de muitos casais aqui. Se essas expressões anunciam efetivamente a verdade, pouco interessa. O que importa é que a vida amorosa narrada feliz é a ficção verdadeira do personagem apaixonado.

Para ilustrar melhor as singularidades dessas narrativas, inferimos que suas especificidades repousam no seguinte conjunto de asserções: nas narrativas de namoros virtuais, a identidade do personagem pode ser descoberta e expressa na experiência da relação amorosa e na compreensão dos sentimentos que se adquire ao contar o trecho da história em que ela se apresenta feliz. São narrativas em que o eu ancora-se na imagem de uma relação afetiva virtual bem-sucedida, tratando-se de um eu emocional, amoroso e, sobretudo, afortunado. Essas narrativas de namoros virtuais presumem compreender vidas comuns como símbolos e expressões de uma relação on-line promissora; são narrativas que coexistem tranquilamente como expressões de sentimentos de tipos amorosos venturosos. Reiteradamente, as representações sobre o eu e o amor felizes estão no centro dessas narrativas, nas quais os envolvidos privilegiam certas histórias de amor e recriam o vivido por meio da seleção de eventos vinculados à felicidade amorosa. Assim, tais narrativas são, intrinsecamente, uma narrativa da memória e da lembrança dos eventos amorosos prósperos, ou seja, em seu epicentro encontra-se a injunção de que o sujeito exerça sua recordação do “amor feliz" para assim (re)vivê-lo em intensidade.

\section{A FICCIONALIZAÇÃO DAS HISTÓRIAS REAIS DE AMORES FELIZES}

Rougemont (2003, p. 24), em sua tese sobre a relação entre amor e sofrimento, enuncia como principal prerrogativa para refletir o romance: "não existe história de amor feliz no Ocidente". Parafraseando-o, esta tese, com base em seu campo empírico, assevera: "não existe história de amor infeliz nos fóruns e enquetes que discutem namoros virtuais". Malgrado a predominância das narrativas que trazem em sua intriga o namoro virtual e a ideia de amor a ele associado como um bem ou o último refúgio da felicidade, há, evidentemente, relatos sobre histórias de amor frustradas. Em menor proporção, registram-se narrativas que associam os namoros virtuais à expressão de sentimentos, como raiva, rancor, tristeza, sofrimento, angústia, desenganos, ansiedades. Há narrativas que deflagram rompimentos de namoros, de casamentos. A presença de narrativas que expressam desavenças, conflitos e desilusões advém de desentendimentos próprios das relações e está relacionada, em muitos casos, a ciúmes, traições, abandonos, brigas etc. 
Para exemplificar melhor a qualidade dessas narrativas que fogem à regra geral, visualizemo-las no quadro abaixo. Elas serão apresentadas, reiteradamente, com o intuito de ratificar o argumento segundo o qual, mesmo com pouca expressão, há narrativas de namoros virtuais que trazem como intriga elementos que contrariam a maioria delas - que é a do sucesso do namoro. Nelas, aparecem as contradições e as incongruências que podem ser tomadas como próprias do campo amoroso virtual. As quatro narrativas que se apresentam a seguir trazem, respectivamente: 1) o tema do sofrimento em função do rompimento amoroso; 2) o relato sobre desentendimentos causados por ciúmes; 3) a expressão da frustração proporcionada por um encontro presencial malsucedido; e, por último, 4) uma narrativa que expressa discordâncias a respeito dos acertos necessários a um possível encontro presencial.

\begin{tabular}{|c|c|}
\hline \multicolumn{2}{|r|}{ Narrativas de namoros virtuais que trazem na intriga elementos conflitantes } \\
\hline $\begin{array}{c}\text { O Fim do } \\
\text { namoro } \\
\text { (Sofrimentos) }\end{array}$ & $\begin{array}{l}\text { É, acabou! O meu sonho, os planos, os desejos... simplesmente acabou. Estou com meu } \\
\text { coração mais que ferido, mais que quebrado. Uma dor que não desejo nem pra meu pior } \\
\text { inimigo. A gente sempre volta, mas dessa vez eu sinto que não dará certo. O que me restou } \\
\text { foi chorar! Tinha até saído da comunidade, mas voltei só pra postar o FIM! Boa sorte a } \\
\text { todas. Fiquem com Deus :( Joana }\end{array}$ \\
\hline $\begin{array}{l}\text { Brigas } \\
\text { (Ciúmes) }\end{array}$ & $\begin{array}{l}\text { Nos conhecemos a } 1 \text { ano e } 5 \text { meses... Estamos juntos a } 2 \text { meses e } 20 \text { dias... Tô MUITO } \\
\text { preocupada com ele, porque por morar longe nosso contato é meio complicado, geralmente } \\
\text { é por mensagens no celular, mas desde ontem a noite ele não manda uma mensagem, por } \\
\text { ciúmes bobos... Não quero perde-lo... =' (Angel }\end{array}$ \\
\hline $\begin{array}{l}\text { Desilusão } \\
\text { (Encontro } \\
\text { presencial } \\
\text { frustrado) }\end{array}$ & $\begin{array}{l}\text { Gente, muito obrigada por tudo. Mas, enfim, eu fui lá [referindo-se ao encontro presencial na } \\
\text { Alemanha], gastei } 30 \text { euros numa ligação. Marquei na estação de trem, porque esse infeliz } \\
\text { tava indo pra Praga. A gente se desencontrou e eu tava sem celular. Não foi dessa vez e não } \\
\text { sei se vou querer ter outra oportunidade. Acho que se ele quisesse me ver, ele teria visto. As } \\
\text { coisas funcionam quando a gente quer que elas funcionem. Eu cansei disso tudo. Eu podia } \\
\text { ter ido pra Inglaterra, que sempre foi meu sonho, mas não, eu fui pra Alemanha só por } \\
\text { causa dele, e ele nem pra reconhecer isso. Não sei o que vai ser, mas vou ter que acostumar } \\
\text { sem ele. Pra mim já chega, já deu o que tinha que dar... :( Lea }\end{array}$ \\
\hline $\begin{array}{l}\text { Discordância } \\
\text { (Acertos do } \\
\text { encontro } \\
\text { presencial) }\end{array}$ & $\begin{array}{l}\text { O que vocês acham? A minha amada mora em Manaus e eu em São Paulo, na capital... } \\
\text { Estamos juntos a } 7 \text { meses, nunca nos vimos, mas, nos amamos desde as primeiras palavras } \\
\text { trocadas no MSN... Infelizmente eu não estou com condições financeiras para ir lá ver ela... } \\
\text { Ela vai tentar vir (eu acho) nas férias dela, que será daqui a } 1 \text { ano... Talvez esse mês ela } \\
\text { viria para BH. Então eu disse para ela passar por aqui, nem que fosse só por um dia... e ela } \\
\text { ficou com raiva, acho que foi porque eu não tomei a iniciativa... Eu só queria sentir a pele } \\
\text { dela... a respiração dela perto do meu rosto... sentir os lábios dela junto dos meus... queria } \\
\text { poder abraçar ela... e não soltar nunca mais... Leandro }\end{array}$ \\
\hline
\end{tabular}

Após a visualização de histórias de amor malogradas, voltemos a discutir a tese segundo a qual predominam narrativas sobre namoros virtuais norteadas por histórias felizes de amor. Nesse ponto, cabe-nos demonstrar empiricamente como aparece, nessas narrativas, a associação entre namoro virtual, amor romântico e felicidade. Para tanto, apresentaremos dois tipos de materiais. O primeiro traz três diferentes postagens recolhidas de um fórum intitulado Conte sua história de amor, no qual se observa o desenvolvimento de narrativas com intrigas 
felizes sobre a experiência de viver o ideal de amor romântico num namoro virtual. Como poderemos notar abaixo, as três postagens apresentam enredos muito parecidos. Na primeira postagem, feita por Carla, a narrativa apresenta o parceiro como alma gêmea; apesar de inúmeros obstáculos, a relação virtual é vista como próspera de modo que, ao cabo, casaramse. A segunda, postada por Pedro, é semelhante à primeira: a parceira é vista como a pessoa que mais amou na vida; apesar dos obstáculos, conseguem ao fim ficar juntos felizes e pra sempre. A última, postada por Victor, de igual modo, toma a parceira como amor da vida. Os obstáculos não o impedirão, enfim, de se encontrarem.

\section{História 1: almas gêmeas, relação amorosa próspera, casamento}

Bom, conheci meu amor na net, numa salinha da MSN, eu era uma das coordenadoras. Ele estava "dando em cima" de uma amiga minha. Ela deu um "fora" nele e eu fui consolar ele. Bem, nos falamos por dois meses pelo MSN. Aí nos falamos pelo telefone e aumentou ainda mais o encantamento. Eu morava em SP capital e ele no interior do RJ. Passado mais um tempo deu certo de nos conhecermos, ele veio até SP e ficou na minha casa um fim de semana. Nossa! Foi tudo lindo, ficamos completamente apaixonados, dali vimos que éramos almas gêmeas mesmo, e ai aconteceu que minha família optou por morar no interior de "sampa". Nossa! Fiquei louca, era mais longe ainda, ele não ia querer mais nada comigo, mas para minha surpresa ele foi lá na minha primeira semana no interior, firmamos o namoro, e ai se passaram dois anos e meio e nesse tempo nos vimos apenas quatro vezes. Quando no fim do ano retrasado ele largou tudo lá na cidade dele, veio pra cá, Ourinhos/SP, arrumou emprego, ficou em república. Namoramos por mais um ano e ai fim do ano passado nos casamos e agora dia 22/10 vamos completar um ano de casados e o amo a cada dia mais. Essa é minha historia gente espero que gostem e boa sorte pra todo mundo (Carla).

História 2: pessoa que mais amei, estamos felizes e é pra sempre

Bem, conheci meu amor numa salinha da AOl. Começamos a teclar e nos aproximamos. Em pouco tempo estávamos muito amigos. Daí surgiu o amor... ainda virtual. Depois nos encontramos e "ficamos". Então o amor só cresceu e começamos a namorar. Namoramos por 2 anos até que ela terminou comigo de um dia para o outro. Fiquei mal, triste, mas segui a minha vida. Namorei outras pessoas. Até que um dia... nos esbarramos novamente na net, 1 ano e quatro meses depois. Acabamos nos reaproximando e ela me confessou que se arrependeu muito que sempre me amou e queria uma segunda chance. Pensei por um tempo. Apesar de amar ela como jamais amei alguém em minha vida e depois de um pouquinho de "migué"...rs acabei aceitando o pedido de perdão dela e o lindo pedido de namoro que ela me fez. Enfim, hoje estamos juntos novamente e muito felizes. Agora é pra sempre !!! (Pedro)

História 3: amor da minha vida, nos encontraremos, enfim A minha historia já dura 4 anos. Pois é, conheci meu amor na internet ha 4 anos atrás numa sala do Uol. Na época teclamos somente nos fim de semana por que eu não tinha net em casa, gastava muito dinheiro e falávamos muito. Depois ela começou a namorar e eu também. Nos afastamos um pouco, mas

DIALEKTIKÉ, v. 1, novembro 2014, p. 134-157

Artigo submetido em setembro/2014 e aceito em outubro/2014 
ela sempre me mandava uns cartões. Passados 4 anos, ela tinha terminado seu segundo relacionamento de 7 meses e eu de 2 anos e meio. Voltamos a teclar novamente. Na segunda vez que teclamos nos declaramos um ao outro e o que era uma amizade passou a ser o amor da vida. Nos damos bem em tudo. Ela me adora em tudo e eu sou completamente apaixonado por ela, sabem aquilo de ficar mal quando não teclamos? Falamos todos os dias e chegamos ao ponto de teclamos 15 horas seguidas. Nunca amei assim na minha vida e nunca fui tão amado. Agora para vocês saberem o nosso drama. Aqui vai o nosso maior problema: sou de Bebedouro, interior de SP, tenho 31 anos e estou há 5 anos em Lisboa-Portugal e ela é de Ribeirão Preto (a $80 \mathrm{~km}$ de Bebedouro) ela tem 21 anos e é a mulher mais linda do mundo. Só nos conhecemos por internet, foto e telefone. Agora em janeiro ela vai vir passear aqui por uma semana. Estou contando os segundos, vai ser a primeira vez que vou poder tocar na mulher da minha vida!!! (Victor)

O segundo material a que nos referimos acima apresenta um quadro no qual as narrativas entrecruzam amor romântico e felicidade, associando-os à pessoa com quem se relaciona (identidade do personagem), ao próprio sentimento amoroso e à relação virtual em si mesma. $\mathrm{O}$ ideal de felicidade atravessa grande parte de nosso material empírico (os fóruns e enquetes que discutem namoros) e, logo abaixo, aparece atrelado, em trechos distintos, ao parceiro(a), ao amor vivido na relação e ao namoro virtual em si.

\begin{tabular}{|c|c|c|}
\hline \multicolumn{3}{|c|}{ ENTRECRUZAMENTO AMOR ROMÂNTICO E FELICIDADE } \\
\hline Parceiro(a) & Sentimento amoroso & Namoro virtual \\
\hline $\begin{array}{l}\text { "Pessoa muito linda”, "Melhor } \\
\text { pessoa do mundo", "Ele é tão } \\
\text { perfeito", "Alguém especial”. }\end{array}$ & $\begin{array}{l}\text { "Foi amor a primeira vista. } \\
\text { Estamos perdidamente } \\
\text { apaixonados". }\end{array}$ & $\begin{array}{l}\text { "É um sonho realizado e } \\
\text { confirmação de deus em nossas } \\
\text { vidas". }\end{array}$ \\
\hline $\begin{array}{l}\text { "Ele é quem eu sempre esperei, } \\
\text { exatamente como eu imaginava". } \\
\text { "Tenho certeza que o quero pelo } \\
\text { resta da vida". }\end{array}$ & $\begin{array}{l}\text { "A sensação é de que o nosso } \\
\text { amor puro só aumenta. É um amor } \\
\text { forte". }\end{array}$ & $\begin{array}{l}\text { "É um encontro de almas. Eterno e } \\
\text { duradouro. É maravilhoso". }\end{array}$ \\
\hline $\begin{array}{l}\text { "É com quem quero constituir } \\
\text { família. Ela me completa. É mesmo } \\
\text { a minha metade". }\end{array}$ & $\begin{array}{l}\text { "É um amor verdadeiro, seguro e } \\
\text { cheio de cumplicidade, admiração } \\
\text { e, principalmente, paixão". }\end{array}$ & $\begin{array}{l}\text { "Namoro virtual só tem dois } \\
\text { finais: ou casa ou falência. Eu vou } \\
\text { casar!" }\end{array}$ \\
\hline $\begin{array}{l}\text { "Somos almas gêmeas. Até no } \\
\text { horóscopo chinês somos o casal } \\
\text { perfeito. Somos o amor da vida um } \\
\text { do outro". }\end{array}$ & $\begin{array}{l}\text { "É um amor que vai aumentada } \\
\text { cada dia mais. É um amor para } \\
\text { sempre". }\end{array}$ & $\begin{array}{l}\text { "Amor de net é verdadeiro, e ponto } \\
\text { final. Tem alta probabilidade de } \\
\text { chegar ao casamento". }\end{array}$ \\
\hline
\end{tabular}

Não há divergências entre o conteúdo das três histórias acima relatadas e o quadro que entrecruza amor romântico e felicidade. Na forma como se organizam no âmbito das narrativas dos fóruns e enquetes, os namoros virtuais e o amor romântico convertem-se em bens supremos, ligados a um ideal de felicidade amorosa. O teor dessas narrativas é desses aspectos tributários. Expressões para referir-se à própria relação virtual e ao amor romântico estão orientadas, concomitantemente, por uma ideia de supremacia quase religiosa, gerando 
uma existência amorosa feliz e plena: é uma benção em minha vida ou é um presente de Deus ou ainda pelo meu amor eu faria tudo. Vale até dar a vida. Elas expressam o caráter superior dessa experiência vivida de maneira tão particular. O namoro virtual e o amor romântico passam a ser vistos como experiências de qualidades elevadas, pois eles estão acima de tudo, sendo comparados à perfeição ou à divindade. O que sentem um pelo outro no âmbito de seus namoros é considerado melhor, mais genuíno, mais pleno, mais realizado, uma vez que são namoros que vêm acompanhados da afeição amorosa romântica.

Depreendemos, a partir do material empírico exposto acima, que são narrativas nas quais o amor romântico e o próprio namoro parecem vencer tudo. Na leitura dos fóruns e enquetes é comum se deparar, a princípio, com queixas, lamúrias ou lamentações referentes à condição de levar a termo um namoro virtual, devido, por exemplo, à distância geográfica que os separa, à ausência da presença física imediata ou à possibilidade de traições e mentiras, mas elas, rapidamente, são revertidas, graças à condição narrativa, em algo positivo e de cunho otimista, de modo que problemas passam a ser vistos de forma idealizada. Por exemplo, uma experiência que pode ser considerada ruim ou negativa, como a expressão da distância que se vê no depoimento meu amor mora a 2900 km longe de mim, é (re)inventada na narrativa como algo positivo sob o argumento de que a distância fortalece o amor, prova de que ele é de fato verdadeiro. Ora, na concepção dos narradores, o amor é capaz de tudo e a distância não é nada para o amor.

Nessas narrativas, impera a máxima segundo a qual nenhum obstáculo vence nosso amor e nosso namoro, porque meu amor é tudo para mim; estou lutando por isso; quando se ama tudo vale à pena. São muitas as expressões que confirmam essa máxima: não há distância que me separe dela; creio que quanto mais a dificuldade melhor a recompensa; a saudade, a distância não abala nossa relação, pelo contrário, cada vez mais nos amamos. $\mathrm{O}$ que interessa reter é que essas expressões ou máximas são reflexos da (re)elaboração do vivido em histórias felizes de amor. Essas narrativas são construídas com elementos da ficção romântica e da própria experiência amorosa vivida. Ademais, interessa-nos aqui ratificar que através dos significados atribuídos ao amor como fonte de felicidade chega-se à identidade do personagem. Não podemos pensar nessas narrativas dissociadas da identidade do personagem, visto que é ele quem narra a história amorosa feliz.

\section{CONSIDERAÇÕES FINAIS}

DIALEKTIKÉ, v. 1, novembro 2014, p. 134-157

Artigo submetido em setembro/2014 e aceito em outubro/2014 
Por fim, resta-nos ainda perguntar: por que são as histórias felizes as escolhidas? Por que contar as histórias de namoros virtuais sob a perspectiva da felicidade amorosa? Temos algumas pistas, duas delas em especial, as quais, longe de se distinguirem, complementam-se: 1) elas são assim apresentadas nos fóruns e enquetes porque trazem em seu conteúdo elementos ficcionais, extraídos tanto do ideal de felicidade romântica quanto da experiência vivida na concretude dos namoros virtuais. Essas duas dimensões se embaralham na narrativa; 2) elas são assim apresentadas nos fóruns e enquetes pois se revestem de uma outra forma possível de (re)viver a experiência amorosa virtual: vivê-la como um sonho romântico. Seria uma maneira possível de concretizar o ideal de amor romântico por meio da narrativa. Reviver sob a forma narrativa uma experiência satisfatória no amor requer auxílio da ficção romântica. A partir dessas pistas, inferimos que as narrativas de namoros virtuais felizes resultam de uma satisfação vivida a qual os narradores colorem, no momento de contá-las, com elementos do romantismo.

Elementos históricos e suas ressonâncias em nossa contemporaneidade, como no caso das concepções românticas de amor, constituem ideais amorosos e de relacionamento que, temos observado, se encontram nas narrativas de namoros virtuais. O romantismo, como bem demonstra Campbell (2001), é mais do que uma prática sentimental, é uma visão de mundo. Do ponto de vista desta pesquisa de tese, isso quer dizer que tanto a imagem do eu (identidade do personagem) quanto a do próprio sentido da experiência dos namoros virtuais podem ser moldadas por essa visão. Nas narrativas de namoros virtuais, o encontro amoroso romântico surge como ideal de felicidade. Elas parecem apregoar que essa felicidade é fundamental, por isso aparecem repetidas vezes: sou muito feliz ao lado dele. É o amor da minha vida; Combinamos de ficarmos cada dia mais felizes, pois temos um ao outro; Estamos muito felizes juntos.

O que queremos enfatizar aqui é que o fenômeno da (re)elaboração e da (re)invenção dos namoros virtuais, na condição narrativa, como razão e causa da felicidade experimentada, está diretamente associado às representação do amor romântico como um ideal socialmente almejado que ocupa ainda um lugar de destaque na vida das pessoas. A expectativa romântica de realização amorosa surge ainda, guardadas as devidas proporções, como garantidora dos sentimentos de completude e felicidade dos indivíduos. De prestígio cultural incontestável, o amor continua apresentando-se como uma das condições para se obter a felicidade numa relação a dois. Martuccelli (2007, p. 402), ao tomar o amor como um "fundamentalismo da 
modernidade", assevera que é absolutamente verdade que boa parte das mais profundas aspirações dos modernos passa pelo amor.

A massificação da ordem romântica se destila no cotidiano através de filmes, de músicas, da publicidade, de novelas etc.; em todas essas representações, o amor romântico é tido como signo da felicidade. Por essas razões, vivê-lo sob a forma narrativa pode ser considerada uma possibilidade promissora, segundo a qual o amor romântico passa a ser uma atividade delirante de palavras ou uma atividade capaz produzir sensações por meio de narrativa. O desejo de viver no tempo e no espaço reais das sequências próprias e consagradas do amor romântico pode ser, aqui, realizado por meio de uma narrativa histórica de ficção. Viver a materialização desse ideal romântico que se convencionou tão sonhado e almejado tornou-se algo de difícil concretude. (ROUGEMONT, 2003; COSTA, 1998, 1999; COSTA, 2005; CARVALHO, 2003). Contudo, na condição narrativa, ele pode ser (re)vivido de forma diferente. Mesmo que os narradores vivam um conjunto de questões difíceis no amor ou na relação virtual, na hora de narrá-las, são as vividas como felizes que ganham destaque. Nesse momento, baseiam-se em suas próprias experiências amorosas on-line e no imaginário romântico, que descreve o amor como sentimento único, sublime, virtuoso etc., como fonte e possibilidade da felicidade. Assim, é essa ideia de amor que tomam de empréstimo para contar a sua própria história encantada de amor.

\section{REFERÊNCIAS}

ABOIM, Sofia. Conjugalidades em mudanças: percursos e dinâmicas da vida a dois. Lisboa: Imprensa de Ciências Sociais, 2006a.

BARTHES, Roland. Fragmentos de um discurso amoroso. Rio de Janeiro: Francisco Alves, 1991.

BENJAMIN, Walter. O narrador. Considerações sobre a obra de Nikolai Leskov. In:

Magia e técnica, arte e política: ensaios sobre literatura e história da cultura. São Paulo: Brasiliense, 1985. (Obras Escolhidas, v. 1).

BOUILLOUD, Jean Philippe. A autobiografia: um desafio epistemológico. In: TAKEUT, Norma; NIEWIADOMSKI, Christophe (Org.). Reinvenções do sujeito social: teorias e práticas biográficas. Porto Alegre: Sulina, 2009.

CARVALHO, Alberto. O amor que rouba os sonhos: um estudo sobre a exposição feminina ao vírus HIV. Rio de Janeiro: Casa do Psicólogo, 1998. 
CARVALHO, Isabel Cristina Moura. Biografia, identidade e narrativa: elementos para uma análise hermenêutica. Horiz. antropol., Porto Alegre, v. 9, n. 19, jul. 2003.

CASTELLS, Manuel. A galáxia da internet: reflexões sobre internet, negócios e sociedade. Fundação Calouste Gulbenkian: Lisboa, 2004.

A sociedade em rede - a era da informação: economia, sociedade e cultura. São Paulo: Paz e Terra, 1999. v. 1.

COSTA, Jurandir Freire. Razões públicas, emoções privadas. Rio de Janeiro: Rocco, 1999.

. Sem fraude nem favor: um estudo sobre o ideal de amor romântico. Rio de Janeiro: Rocco, 1998.

COSTA, Sérgio. Amores fáceis: romantismo e consumo na modernidade tardia. Novos estud. - CEBRAP, São Paulo, n. 73, nov. 2005.

CAMPBEll, Colin. A Ética Romântica e o Espírito do Consumismo Moderno. Rio de Janeiro: Rocco, 2001.

DELORY-MOMBERGER, Christene. Biografia e educação: figuras do indivíduo-projeto. Natal: Editora da UFRN; São Paulo: Paulus, 2008.

FOUCAULT, Michael. A hermenêutica do sujeito. São Paulo: Martins Fontes, 2006.

GIDDENS, Anthony. A transformação da intimidade: sexualidade, amor e erotismo nas sociedades modernas. São Paulo: Editora da UNESP, 1993.

ILLOUZ, Eva. O amor nos tempos do capitalismo. Rio de Janeiro: Zahar, 2011.

MARTUCELLI, Danilo. Gramáticas del individuo. Buenos Aires: Losada, 2007.

RICOEUR, Paul. A identidade narrativa e o problema da identidade pessoal. Tradução de Carlos João Correia. Arquipélago, Lisboa, n. 7, p. 177-194, 2000.

. Tempo e narrativa (Tomo I). Campinas: Papirus, 1994.

Tempo e narrativa (Tomo II). Campinas: Papirus, 1995.

Tempo e narrativa (Tomo III). Campinas: Papirus, 1997.

O si-mesmo como um outro. São Paulo: Papirus, 1991.

ROUGEMONT, Denis. A história do amor no Ocidente. São Paulo: Ediouro, 2003.

WHITE, Hayden. As ficções da representação factual. In: WHITE, Hayden. Trópicos do discurso. São Paulo: Editora da USP, 1994. 